in the Queen's University, and in 1947 he became also chief scientific officer, Ministry of Agriculture for Northern Ireland. He has represented Queen's University on the Inter-University Council for Higher Education in the Colonies and has visited the West Indies on two occasions in connexion with the University College of the West Indies. Prof. Baskett's research work has been mainly concerned with problems in animal nutrition, particularly in the mineral requirements of pigs and poultry, the effects of feoding on the quality of bacon and studies on nutritional anæmia in young pigs.

Mr. W. F. Darke, at present secretary (agriculture) in the office of the United Kingdom High Commissioner in Ottawa, has been appointed agricultural adviser to the High Commissioner and will no longer act as assistant to the agricultural attache in Washington.

\section{Aircraft De-icing Research}

THe Royal Canadian Air Force, Engineering Division, has carried out investigations upon aircraft de-icing for some time past, and now considers that thermal de-icing, or actually anti-icing, appears to hold more promise than either the heated surface, mechanical pulsation, or chemical treatment hitherto employed. It has equipped a large four-engined Rolls-Royce Merlin-powered 'North Star' aircraft with the necessary apparatus for flying tests and observation, and intends to collect meteorological data upon cloud conditions, in a more detailed and precise fashion than has been possible before, as well as to experiment upon the dispersal or prevention of ice accretions.

The principal feature of the 'Ice Wagon' is a large 'shark's fin' on the top of the body. This will be fitted with the electro-thermal de-icing devices, and has blister-type observation domes on either side from which an operator can study and control the ice-shedding process during flight. The propellers are also fitted with similar electric blade-heating, and these are observed either through a stroboscopic viewer, or by stopping the propeller temporarily. The general principle of the new technique is one of intermittent flow of current along wires installed at places where the ice that is forming is most readily dislodged. This is considered to be more efficient than continuous heating of a surface. The consider able electric energy for this, and the various electrical photographic recorders, is supplied by two enginedriven alternators, delivering $60 \mathrm{~kW}$., 208 volts, 3 -phase, 400 cycles. The equipment of this machine is based upon tests already carried out in test chambers in a low-temperature laboratory.

\section{Operational Research Quarterly}

THE main purpose of the new periodical, Operational Research Quarterly, of which the first number was published in March (1, No. 1; pp. 16 ; London : Operational Research Club, 25 Buckingham Gate, London, S.W.1, $1950 ; 3 s$. or $10 s$. a year), is to assemble in one place as much as possible of the information that workers in this field require and which at present is scattered over a very wide range of scientific and technical literature. The abstracts are intended primarily to facilitate access to the original sources, and, although in the first issue they are in general historical, the range of journals from which they are taken is sufficiently wide to provide prima facie justification for the new periodical. They also illustrate the four main headings under which operational research is grouped: studies of human, behaviour by itself, in which group applications in the field of economies are conveniently included; "man and his machines", covering most industrial and military applications ; "traffic and flow"; and general papers, including those concerned with the organisation and purposes of operational research itself. It is also proposed to include in each issue an original and provocative article on some aspects of operational research, and the first of these is contributed by Prof. P. M. S. Blackett. In this article he urges that the element of relative novelty of operational research is not so much in the material to which the scientific method is applied as in the level at which the work is done, in the comparative freedom of the investigators to seek out their own problems, and in the direct relation of the work to the possibilities of executive action. The second issue of the journal (June) is on similar lines to the first, the main article being an account by L. H. C. Tippett of the use made of operational research methods in the Shirley Institute, the headquarters of the British Cotton Industry Research Association.

\section{Institution of Electrical Engineers: Premium Awards}

THE Institution of Electrical Engineers has made the following awards of premiums for papers read or accepted for publication during the session 1949-50. Institution Premium: Dr. J. D. McGee. Kelvin Premium: Prof. H. G. Booker and P. C. Clemmow. John Hopkinson Premium: D. W. Fry, J. Dain, H. H. H. Watson and H. E. Payne; F. K. Goward, J. D. Lawson, J. J. Wilkins and R. Carruthers. NonSection Premiums: Dr. P. F. Soper (Llewellyn B. Atkinson Premium); H. R. Broadbent; C. M. Cock; L. H. A. Carr. Measurements Section Premiums : W. S. Melville (Silvanus Thompson Premium); R. O. Carter and D. L. Richards (Mather Premium); S. F. Musson and R. E. Mell ; A. R. Boothroyd, E. C. Cherry and R. Makar ; Prof. F. C. Williams and S. W. Noble; K. H. Stewart; N. F. Astbury, Dr. T. Emmerson and J. McFarlane. Radio Section Premiums : Dr. F. E. Jones and E. C. Cornford (Duddell Premium); Dr. L. G. H. Huxley and J. A. Ratcliffe (Ambrose Fleming Premium); Dr. E. L. C. White and M. G. Harker ; Dr. J. L. Pawsey; B. Y. Mills; W. T. Duerdoth; J. E. N. Hooper and A. A. Kippax; S. de Walden and J. C. Swallow; G. Millington and G. A. Isted. Supply Section Premıums : A. T. Chadwick, J. M. Ferguson, D. H. Ryder and G. F. Stearn (Sebastian de Ferranti Premium) ; Dr. J. S. Forrest (John Snell Premium); G. Lyon. Utilization Section Premiums : F. W. Cox and W. E. Swale (Crompton Premium); R. T. Coe and D. F. Welch (Swan Premium); A. R. H. Thorne. Fahie Premium: T. H. Flowers and D. A. Weir. Heaviside Premium : H. J. Josephs. Paris Exhibition (1881) Premium : L. Gosland. Overseas Premiums (for senior members) : A. J. G. Gosling ; (for students and graduates): J. W. Crompton.

\section{International Optical Commission}

Mentings of the International Optical Commission will be held in London in the apartments of the Royal Society during July 17-18. The Commission, which is part of the International Union of Pure and Applied Physics, was constituted at Delft in 1948 after a preparatory meeting in Prague in 1947, and its purpose is to further international scientific 